\title{
Психологічні особливості підлітків із псоріазом
}

\section{Е.О. Мурзіна', Л.В. П'янківська', Ю.А. Рохлецова², К.О. Бардова'}

'Національний університет охорони здоров'я України імені П.Л. Шупика, Київ, Україна

${ }^{2}$ Київський національний університет імені Тараса Шевченка, Київ, Україна

Анотація. Оцінка психологічних особливостей підлітків із псоріазом віком 13-17 років за Багатофакторним особистісним опитувальником Р.Б. Кеттелла виявила низький рівень вираженості особистісних рис, які в 9 з 14 факторів у хлопців та в 13 із $14-$ у дівчат статистично значущо нижчі за нормативні показники. Отримані результати дали можливість окреслити психологічний портрет хлопців із псоріазом як обережних, стриманих, поступливих, поверхневих у роботі та в соціальних контактах, чутливих та довірливих до близьких людей і залежних від значимих осіб. Причиною непорозумінь та звуженого кола спілкування можуть слугувати негнучкість і непоспішність у їх поведінці. Наявність поведінкових реакцій з мінливістю настрою й різноспрямованих тенденцій урівноваженості можна пов'язати з особливостями перебігу захворювання та підлітковим віком. Дівчата з псоріазом — недостатньо товариські, обережні та стримані в соціальних контактах, мають відчуття неповноцінності - це може спричинити замкнутість, відокремленість та соціальну ізольованість. Вони потребують підтримки та можуть бути нав'язливими. Прояви недостатньо сформованих емоційно-вольових особливостей відмічають залежно від соціального середовища, ситуації та перебігу захворювання.

Ключові слова: псоріаз, підлітки, психологічні особливості, особистісні риси характеру.

\section{Вступ}

Існує низка дерматологічних захворювань, для яких характерна наявність стресової або травматичної ситуації для маніфестації захворювання або чергового загострення, до яких належить і псоріаз. До групи ризику виникнення цього дерматозу відносять людей із певними особистісними характеристиками. Це невпевнені у собі, нерішучі особи зі слабкою нервовою системою, яким будь-який вибір дається дуже нелегко. Вони схильні до побоювань, образливі та пасивні [1]. Найчастішими емоційними симптомами для них $\epsilon$ страх, депресія та суїцидальні тенденції [2]. Пацієнтам із шкірними захворюваннями властиві відчуття соціальної та фізичної неповноцінності, у них загострене сприйняття реакцій оточуючих, що посилює в таких хворих емоційну напруженість, тривожність, підозрілість і настороженість [3].

Шкірні психосоматичні захворювання у своєму розвитку мають, перш за все, генетичну та імунологічну основу. Психогенні впливи призводять до загострення дерматозу лише в тісному зв'язку з основними факторами патогенезу. Провокуюча роль психогенних факторів у виникненні та перебігу псоріазу описані в багаточисленних спостереженнях. У маніфестації та розвитку псоріазу підтверджена роль психогенної травми, розумової перевтоми [4-6]. Загострення псоріазу після гострих нервово-психічних потрясінь, негативних емоцій і нервового перенапруження відмічають у 52,5\% хворих. Більше 50\% пацієнтів пов'язують розвиток псоріазу з вираженими негативними емоціями, тяжкими психічними потрясіннями, причому у $1 / 3$ хворих інтервал між причиною і наслідком становив близько 2-14 днів, у інших не більше 3 тиж [7-9].

Наявність видимих проявів псоріазу стає додатковим психотравмуючим фактором, який $\epsilon$ дуже стресовим для дітей, призводить до зниження самооцінки, викликає фрустрацію, що може проявлятися різноманітними дисфункціональними реакціями. Помітні косметичні вади можуть призвести до соціальної дезадаптації з втратою багатьох інтересів [10-12]. Пацієнти висловлюють стурбованість 3 приводу постійного лущення шкіри, появи запаху від шкірного висипу. Ці фактори негативно впливають на активність у 15-30\% дітей із псоріазом. Така стигматизація може призвести до поведінкових змін, депресії, тривоги [13].

У попередньому дослідженні «намальований психологічний портрет» підлітка із псоріазом [14]. Але залежно від статі риси характеру дітей із псоріазом не були описані.

Мета дослідження: виявити психологічні особливості хлопців та дівчат із псоріазом віком 13-17 років.

\section{Об'єкт і методи дослідження}

У дослідженні взяли учать 15 хлопців та 15 дівчат із псоріазом віком 13-17 років, які лікувалися стаціонарно та амбулаторно в КНП «Київська міська клінічна шкірно-венерологічна лікарня» взимку 2020-2021рр. Діагноз встановлювали за загальноприйнятими клінічними критеріями.

Характерологічні та поведінкові риси хлопців та дівчат із псоріазом оцінювали за допомогою Багатофакторного особистісного опитувальника Р.Б. Кеттелла, підлітковий варіант методики використовують у дітей віком 13-18 років. Тести надавали дітям у друкованому вигляді. Підліткова 14-факторна методика містить 142 запитання з трьома варіантами відповідей. Після проведеного інструктажу діти самостійно відповідали на них. Далі проводили підрахунок кількості збігів відповідей з ключем. Отриману суму балів з урахуванням статі та віку дитини порівнювали з нормативними даними таблиці. За результатами порівняння вираженість фактора оцінювали як низьку, середню або високу [15].

Ключові особистісні риси підлітків із псоріазом розкривалися через дослідження переваг у таких біполярних факторах: A «шизотимія-афектотимія», C «ступінь емоційної стійкості», D «флегматичність-збудливість», $\mathrm{E}$ «пасивність-домінантність», F «десургенсія-сургенсія», G «ступінь прийняття моральних норм», H «сором'язливість-авантюризм», I «реалістичністьсенситивність», J «неврастенія-фактор Гамлета», О «самовпевненість-відчуття провини», Q2 «ступінь групової залежності», Q3 «ступінь самоконтролю», Q4 «ступінь внутрішньої напруги».

Матеріали дослідження статистично оброблені за допомогою програми «StatTech v. 1.2.0» («StatTech», Росія). Кількісні дані, що мали нормальний розподіл, описували за допомогою середніх арифметичних величин (М) та стандартного відхилення (SD). Для порівняння груп за кількісними показниками для двох зв'язаних вибірок використовували парний t-критерій Стьюдента.

\section{Результати та їх обговорення}

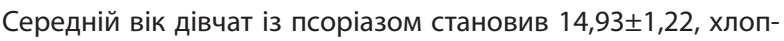
ців - 14,93 $\pm 1,44$ року.

Виявлення особистісних рис підлітків із псоріазом проводили за допомогою компонування факторів за вираженістю комунікативного та емоційно-вольового компонентів.

Порівняльний аналіз усереднених результатів за 14 факторами характерологічних особливостей хлопців із псоріазом та показниками норми та дівчат із псоріазом та показниками норми 
виявив статистично значущі розбіжності як у дівчат, так і у хлопців, причому в дівчат статистичні розбіжності між отриманими показниками та показниками норми виявлені в 13 з 14 факторів, а в хлопців - в 9 із 14 факторів (табл. 1).

Таблиця 1 Порівняння показників вираженості факторів у хлопців та дівчат із псоріазом з нормативними показниками

\begin{tabular}{|c|c|c|c|c|}
\hline \multirow[b]{2}{*}{ Фактор } & \multicolumn{2}{|c|}{ Хлопці } & \multicolumn{2}{|c|}{ Дівчата } \\
\hline & $\begin{array}{c}\text { Отримані } \\
\text { показники }\end{array}$ & $\begin{array}{l}\text { Нормативні } \\
\text { показники }\end{array}$ & $\begin{array}{c}\text { Отримані } \\
\text { показники }\end{array}$ & $\begin{array}{l}\text { Нормативні } \\
\text { показники }\end{array}$ \\
\hline \multirow[t]{2}{*}{ A } & $12,07 \pm 0,88$ & $12,54+0,22$ & $8,0 \pm 0,91$ & $13,48 \pm 0,16$ \\
\hline & \multicolumn{2}{|c|}{0,317} & \multicolumn{2}{|c|}{$<0,001^{*}$} \\
\hline \multirow[t]{2}{*}{$B$} & $4,6 \pm 0,84$ & $4,4 \pm 0,07$ & $3,2 \pm 0,42$ & $4,26 \pm 0,19$ \\
\hline & \multicolumn{2}{|c|}{0,406} & \multicolumn{2}{|c|}{$0,011^{*}$} \\
\hline \multirow[t]{2}{*}{$C$} & $11,67 \pm 1,25$ & $13,27 \pm 0,31$ & $6,6 \pm 1,05$ & $10,78 \pm 0,19$ \\
\hline & \multicolumn{2}{|c|}{0,127} & \multicolumn{2}{|c|}{$<0,001^{*}$} \\
\hline \multirow[t]{2}{*}{ D } & $7,0 \pm 1,29$ & $12,75 \pm 0,28$ & $8,93 \pm 0,91$ & $14,08 \pm 0,13$ \\
\hline & \multicolumn{2}{|c|}{$<0,001^{*}$} & \multicolumn{2}{|c|}{$<0,001^{*}$} \\
\hline \multirow[t]{2}{*}{$\mathrm{E}$} & $11,47 \pm 0,74$ & $14,3 \pm 0,74$ & $8,53 \pm 0,79$ & $13,73 \pm 0,12$ \\
\hline & \multicolumn{2}{|c|}{$0,001^{*}$} & \multicolumn{2}{|c|}{$<0,001^{*}$} \\
\hline \multirow[t]{2}{*}{$\mathrm{F}$} & $7,07 \pm 0,84$ & $13,8 \pm 0,14$ & $10,27 \pm 1,1$ & $14,420,18$ \\
\hline & \multicolumn{2}{|c|}{$<0,001^{*}$} & \multicolumn{2}{|c|}{$<0,001^{*}$} \\
\hline \multirow[t]{2}{*}{$G$} & $12,27 \pm 1,27$ & $14,0 \pm 0,15$ & $9,6 \pm 0,99$ & $13,63 \pm 0,27$ \\
\hline & \multicolumn{2}{|c|}{0,1} & \multicolumn{2}{|c|}{$<0,001^{*}$} \\
\hline \multirow[t]{2}{*}{$\mathrm{H}$} & $11,53 \pm 1,29$ & $14,26 \pm 0,24$ & $8,67 \pm 0,79$ & $12,71 \pm 0,13$ \\
\hline & \multicolumn{2}{|c|}{$0,023^{*}$} & \multicolumn{2}{|c|}{$<0,001^{*}$} \\
\hline \multirow[t]{2}{*}{1} & $8,47 \pm 1,37$ & $8,81 \pm 0,87$ & $9,47 \pm 0,9$ & $12,36 \pm 1,38$ \\
\hline & \multicolumn{2}{|c|}{0,417} & \multicolumn{2}{|c|}{0,058} \\
\hline \multirow[t]{2}{*}{ J } & $7,4 \pm 1,0$ & $12,93 \pm 0,18$ & $9,33 \pm 1,01$ & $11,45 \pm 0,24$ \\
\hline & \multicolumn{2}{|c|}{$<0,001^{*}$} & & \\
\hline 0 & $5,27 \pm 1,01$ & $13,57 \pm 0,43$ & $7,6 \pm 1,11$ & $15,03 \pm 0,21$ \\
\hline & & & & \\
\hline Q2 & $8,73 \pm 1,05$ & $14,17 \pm 0,16$ & $5,87 \pm 1,17$ & $13,58 \pm 0,11$ \\
\hline & & & & \\
\hline Q3 & $10,47 \pm 0,98$ & $14,44 \pm 0,2$ & $8,13 \pm 0,79$ & $14,13 \pm 0,24$ \\
\hline & & & & \\
\hline Q4 & $7,4 \pm 0,97$ & $13,4 \pm 0,14$ & $8,4 \pm 0,99$ & $14,36 \pm 0,26$ \\
\hline & & & & \\
\hline
\end{tabular}

*Розбіжності показників статистично значущі; $\mathrm{p}<0,05$.

Усереднені показники факторів в дівчат більш занижені, але майже рівномірно за всіма показниками. Щодо показників у хлопців із псоріазом, бачимо явні провали за показниками факторів D «флегматичність-збудливість», F «десургенція-сургенція» та O «самовпевненість-відчуття провини» (рисунок).

Рисунок Графіки показників вираженості факторів у хлопців та дівчат із псоріазом та графіки нормативних показників

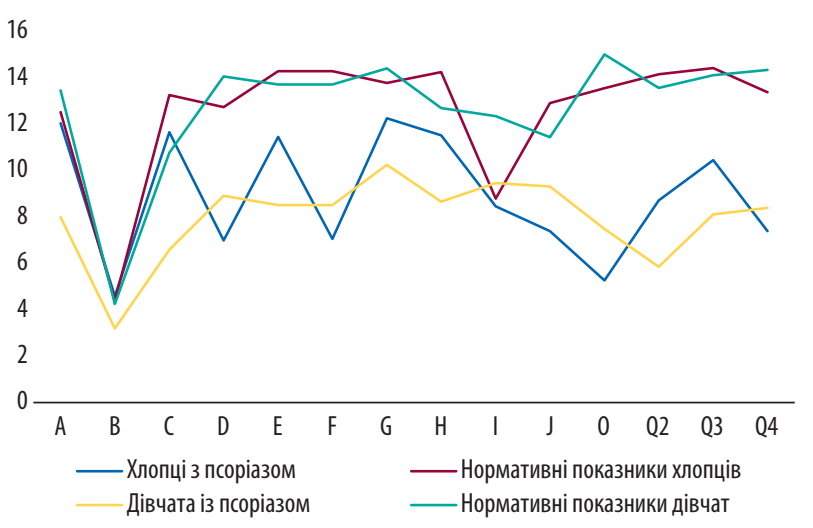

Це надає можливість стверджувати, що дівчата з псоріазом більш замкнені, досить схильні до ізольованості, але емоційно нестійкі та імпульсивні, потребують більшої підтримки соціуму та залежні від авторитетних осіб порівняно з групою досліджуваних хлопців. Для хлопців характерні більша рівність настрою, обережність, неспішність, небагатослівність, самовпевненість, довірливість, більша нормативність поведінки порівняно з групою дівчат, але саме хлопці більше прагнуть уваги та соціальної взаємодії.

При аналізі характерологічних особливостей хлопців із псоріазом встановлено, що більшість із них за усіма факторами методики мали низький рівень вираженості особистісних рис. Але за трьома факторами («шкала брехні», «шизотимія», «ступінь емоційної стійкості») відповіді розділилися майже порівну на низькі та високі показники (табл. 2). Високий рівень фактора В у 46,67\% хлопців із псоріазом характеризує їх як орієнтованих на соціально-бажану поведінку й певну демонстративність.

Таблиця 2 Розподіл вираженості факторів - особистісних рис хлопців із псоріазом

\begin{tabular}{|c|c|c|c|c|c|c|c|}
\hline \multirow{3}{*}{\multicolumn{2}{|c|}{ Фактор }} & \multicolumn{6}{|c|}{ Вираженість фактора } \\
\hline & & \multicolumn{2}{|c|}{ Висока } & \multicolumn{2}{|c|}{ Середня } & \multicolumn{2}{|c|}{ Низька } \\
\hline & & $\begin{array}{c}\text { Абсо- } \\
\text { лютний } \\
\text { показ- } \\
\text { ник }\end{array}$ & $\%$ & $\begin{array}{c}\text { Абсо- } \\
\text { лютний } \\
\text { показ- } \\
\text { ник }\end{array}$ & $\%$ & $\begin{array}{c}\text { Абсо- } \\
\text { лютний } \\
\text { показ- } \\
\text { ник }\end{array}$ & $\%$ \\
\hline A & Шизотимія-афектотимія & 6 & 40 & 2 & 13,33 & 7 & 46,67 \\
\hline B & Шкала брехні & 7 & 46,67 & - & - & 8 & 53,33 \\
\hline$c$ & Ступінь емоційної стійкості & 6 & 40 & 1 & 6,67 & 8 & 53,33 \\
\hline D & Флегматичність-збудливість & 2 & 13,33 & 1 & 6,67 & 12 & 80 \\
\hline $\mathrm{E}$ & Пасивність-домінантність & 1 & 6,67 & 3 & 20 & 11 & 73,33 \\
\hline $\mathrm{F}$ & Десургенсія-сургенсія & - & - & - & - & 15 & 100 \\
\hline$G$ & Суупінь прийняття моральних норм & 5 & 33,33 & 3 & 20 & 7 & 46,67 \\
\hline $\mathrm{H}$ & Сором'язливість-авантюризм & 3 & 20 & 4 & 26,67 & 8 & 53,33 \\
\hline I & Реалістичність-сенситивність & 4 & 26 & 2 & 13,33 & 9 & 60 \\
\hline J & Неврастенія-фактор Гамлета & 1 & 6,67 & 1 & 6,67 & 13 & 86,67 \\
\hline 0 & Самовпевненість-відчуття провини & 1 & 6,67 & 1 & 6,67 & 13 & 86,67 \\
\hline Q2 & Ступінь групової залежності & 2 & 13,33 & - & - & 13 & 86,67 \\
\hline 03 & Ступінь самоконтролю & 1 & 6,67 & 3 & 20 & 11 & 73,33 \\
\hline Q4 & Ступінь внутрішньої напруги & 1 & 6,67 & - & - & 14 & 93,33 \\
\hline
\end{tabular}

Зниження показників за фактором А у 46,67\% хлопців із псоріазом вказує на прояви ригідності, схильності до усамітнення, скептичності, негнучкості у поведінці та уникнення соціальних контактів. Високі показники вираженості у $40 \%$ хлопців засвідчують їх доброзичливість, схильність до співчуття, гнучкість поведінкових реакцій, соціальну спрямованість особистості та достатню адаптованість.

Більшість хлопців (86,67\% за фактором Q2) в комунікативній сфері прагнуть до соціальної підтримки та схвалення, демонструють коректність та поступливість, прагнення розкритися й виговоритися тому, кому довіряють (73,33\% за фактором Е). Але в 53,33\% хлопців цьому перешкоджають деяка обережність, прагнення до усамітнення та обмеженість кола спілкування, емоційна вразливість та індивідуальність у поведінці, що може бути сформовано під впливом захворювання (низька вираженість за фактором Н).

При оцінці емоційно-вольових характеристик хлопців із псоріазом визначено, що 93,33\% підліткам з низьким рівнем фактора Q4 притаманна знижена мотивація досягнень та продуктивність діяльності. У 86,67\% хлопців із псоріазом за фактором J констатоване їх соціальне спрямування на групову діяльність, прийняття соціальних норм і правил поведінки. Низький рівень сформованості фактора Q3 в 73,33\% хлопців свідчить про недостатність самоконтролю поведінки та організованості, уникнення соціальних вимог порушує їх адаптованість у соціумі.

Хлопці з псоріазом з низьким рівнем вираженості за фактором I (60,0\%) реалістичні в оцінці подій, прагнуть до незалежності, але мають жорсткість характеру та скептичність щодо соціально-культурних аспектів життя. 26,0\% підліткам властиві протилежні характеристики: підвищена тривожність, чутливість, 
нетерплячість. Вони виявляють творчий потенціал, але водночас залежні від оточуючих та прагнуть їх уваги.

Ступінь емоційної стійкості у 53,33\% хлопців із низьким рівнем фактора С вказує на мінливість у них настрою та поведінкових реакцій, прагнення до задоволення власних потреб, емоційну збудливість, дратівливість. Водночас високі показники фактора встановлені у 40,0\% осіб. Це підлітки зі зрілою життєвою позицією, гнучкою поведінкою, схильністю до дотримання суспільних норм поведінки.

46,67\% хлопців з низьким рівнем сформованості за фактором $\mathrm{G}$ характеризуються недостатнім усвідомленням та виконанням соціально-культурних вимог. Їм притаманні деяка егоїстичність, поверховість у діяльності, необов'язковість у виконанні завдань, але наявна хороша стресостійкість. Разом з цим у 33,33\% хлопців встановлено високі показники за фактором G. Цим підліткам притаманні відповідальність, вимогливість до себе та інших осіб, обов'язковість, педантичність.

Отже, за результатами дослідження комунікативних здібностей встановлено, що хлопцям із псоріазом притаманні поступливість, чутливість, обережність, але довірливість значимим близьким та залежність від авторитетних осіб. Непоспіх у діях, настороженість та негнучкість можуть спричиняти непорозуміння й призводити до звуженого кола спілкування. На деяку відокремленість та ізольованість від соціального середовища можуть впливати особливості захворювання. Емоційно-вольові характеристики хлопців із псоріазом - це довірливість, стриманість, прагнення до незалежності та реалістичності, постійність інтересів та захоплень. Зниження мотивації та продуктивності діяльності призводить до поверховості в роботі та соціальних контактах. Урівноваженість настрою й поведінкових реакцій, що межує з мінливістю, можна пов'язати з підлітковим віком та особливостями перебігу захворювання. Водночас хлопці з псоріазом схильні дотримуватися загальноприйнятих соціальних норм, але з деякою скептичністю щодо соціально-культурних аспектів життя.

Для більшості дівчат із псоріазом аналіз особистісних характеристик констатував знижений рівень майже усіх факторів за опитувальником Р.Б. Кеттелла. Щодо щирості відповідей загалом більшість дівчат відповідали відверто й не прикрашали власних якостей (табл. 3).

Таблиця 3 Розподіл вираженості факторів - особистісних рис серед дівчат із псоріазом

\begin{tabular}{|c|c|c|c|c|c|c|c|}
\hline & \multirow{3}{*}{ Фактор } & \multicolumn{6}{|c|}{ Вираженість фактору } \\
\hline & & \multicolumn{2}{|c|}{ Висока } & \multicolumn{2}{|c|}{ Середня } & \multicolumn{2}{|c|}{ Низька } \\
\hline & & $\begin{array}{l}\text { Абсо- } \\
\text { лютний } \\
\text { показ- } \\
\text { ник }\end{array}$ & $\%$ & $\begin{array}{l}\text { Абсо- } \\
\text { лютний } \\
\text { показ- } \\
\text { ник }\end{array}$ & $\%$ & $\begin{array}{l}\text { Абсо- } \\
\text { лютний } \\
\text { показ- } \\
\text { ник }\end{array}$ & $\%$ \\
\hline $\mathrm{A}$ & Шизотимія-афектотимія & - & - & 1 & 6,67 & 14 & 93,33 \\
\hline$B$ & Шкала брехні & 2 & 13,33 & 4 & 26,67 & 9 & 60 \\
\hline$c$ & Ступінь емоційної стійкості & 1 & 6,67 & - & - & 14 & 93,33 \\
\hline$D$ & Флегматичність-збудливість & - & - & 3 & 20 & 12 & 80 \\
\hline $\mathrm{E}$ & Пасивність-домінантність & - & - & - & - & 15 & 100 \\
\hline $\mathrm{F}$ & Десургенсія-сургенсія & - & - & 2 & 13,33 & 13 & 86,67 \\
\hline$G$ & Ступінь прийняття моральних норм & 3 & 20 & 1 & 6,67 & 11 & 73,33 \\
\hline $\mathrm{H}$ & Сором'язливість-авантюризм & - & - & 2 & 13,33 & 13 & 86,67 \\
\hline I & Реалістичність-сенситивність & 2 & 13,33 & 1 & 6,67 & 11 & 73,33 \\
\hline J & Неврастенія-фактор Гамлета & 3 & 20 & - & - & 12 & 80 \\
\hline 0 & Самовпевненість-відчуттяпровини & - & - & 2 & 20 & 13 & 86,67 \\
\hline Q2 & Ступінь групової залежності & 1 & 6,67 & 1 & 6,67 & 13 & 86,67 \\
\hline Q3 & Суупінь самоконтролю & 1 & 6,67 & - & - & 14 & 93,33 \\
\hline Q4 & Ступінь внутрішньої напруги & 1 & 6,67 & 1 & 6,67 & 13 & 86,67 \\
\hline
\end{tabular}

За фактором Е у 100\% дівчат із псоріазом наявна особистісна незрілість. Для них характерні поступливість в усьому та нав'язливість у поведінці. 93,33\% дівчат з низьким рівнем сформованості за фактором А притаманні замкнутість й недостатня дружелюбність, скептичність, ригідність у діях та установках. За факторами F, Н та Q2 86,67\% дівчат із псоріазом сором'язливі, вразливі, обережні, неспішні в діях, мають прояви похмурого настрою. Їм притаманні уникання самопредставлення, соціальних контактів та відчуття неповноцінності. «Мисляча інтроверсія» у дівчат із псоріазом виражається залежністю від оточуючих, прагненням приймати рішення спільно з групою, потребою підтримки близького соціального середовища.

Аналіз емоційно-вольових характеристик дівчат із псоріазом виявив в 93,33\% випадках низький рівень сформованості за факторами C та Q3, що вказує на слабкість нервової системи. Для дівчат характерні прояви емоційної чутливості, вразливість, мінливість настрою та підвищена імпульсивність 3 прагненням термінового задоволення власних потреб. Вони слабо контролюють свою поведінку, можуть бути імпульсивними, уникати соціальних вимог.

За низькими показниками факторів О та Q4 в 86,67\% дівчат прояви спокою межують з деякою в'ялістю. Вони довірливі, схильні до самозадоволеності. 80,0\% дівчат за фактором D вирізняються інертністю у поведінці, спокоєм, наполегливістю у досягненні поставлених цілей. У 73,33\% дівчат наявні прояви егоїстичності, поверховості у контактах, виконанні завдань та досягненні цілей, незалежності від групових правил, на що вказує низький рівень фактора $\mathrm{G}$, а також практичності, жорсткості, реалістичності поглядів на життя й водночас самовпевненості та скептичності (за низьким рівнем вираженості фактора I).

У 80,0\% дівчат із псоріазом фактор J «неврастенія - фактор Гамлета» виявляється низьким рівнем сформованості: вони залежні від групи, але прагнуть привернути увагу до себе, що може свідчити про недостатність соціальної уваги або через особливості захворювання.

Отже, загалом комунікативну сферу досліджуваних дівчат із псоріазом можна охарактеризувати як недостатньо сформовану. Дівчата обережні та стримані у соціальних контактах, недостатньо дружелюбні й не прагнуть до самопредставлення. Притаманні їм відчуття неповноцінності, сповільненість мови й утрудненість у висловлюваннях можуть призводити до відокремленості та замкнутості. Водночас у близькому оточенні вони можуть бути нав'язливими, потребувати підтримки й бути залежними від інших. Щодо емоційно-вольових характеристик дівчат із псоріазом отримані результати дають можливість констатувати подвійність проявів залежно від ситуації та соціального середовища. 3 одного боку, спокій, інертність, стриманість, емоційна чутливість і вразливість, що поєднуються з імпульсивністю та мінливістю настрою, можуть проявлятися недостатністю самоконтролю власної поведінки. 3 іншого - егоїстичність, схильність до задоволення власних потреб та наполегливість у їх досягненні призводять до уникання загальноприйнятих норм поведінки. Поверховість у діяльності та зниження відчуття небезпеки вказують на ускладнену адаптацію дівчат із псоріазом у соціумі.

\section{ВиснОВКИ}

1. Аналіз результатів дослідження за Багатофакторним особистісним опитувальником Р.Б. Кеттелла (підлітковий варіант) встановив, що хлопцям та дівчатам із псоріазом притаманні занижені показники більшості досліджуваних факторів.

2. Для хлопців із псоріазом характерні обережність, стриманість, поступливість, поверховість у роботі та соціальних контактах, довірливість близьким людям і залежність від значимих осіб. Водночас неспішність й негнучкість у їх поведінці можуть слугувати причиною непорозумінь та звуженого кола спілкування. Вони прагнуть дотримуватися загальноприйнятих соціальних норм, але виявляють цинічність щодо соціальних аспектів життя. В них відмічають різноспрямованість тенденцій урівноваженості настрою й поведінкових реакцій з мінливістю, що можна пов'язати з підлітковим віком та особливостями перебігу захворювання.

3. У дівчат із псоріазом констатована більша заниженість показників за факторами опитувальника порівняно з хлопцями, 
що зумовлює в них такі особливості, як обережність і стриманість у соціальних контактах, недостатня товариськість та відчуття неповноцінності, що можуть спричиняти відокремленість, замкнутість та соціальну ізольованість. Дівчата можуть бути нав'язливими й потребувати підтримки. Емоційно-вольові особливості в них недостатньо сформовані та проявляються залежно від ситуації, соціального середовища і перебігу захворювання.

\section{Список використаної літератури/References:}

1. Mendelevich V.D. Solovieva S.L. (2002) Neurosology and psychosomatic medicine. Medpressinform, Moscow, 608 p. (In Rus.).

2. Luban-Plozza V., Peldinger V., Kroger F. (1994) Psychosomatic patient at the doctor's appointment. NIPI of V.M. Bekhterev, St. Petersburg, 245 p. (In Rus.).

3. Papiy N.A. (2001) Skin diseases: psychodiagnostics and psychocorrection. Polymya, Minsk, 176 p. (In Rus.).

4. BodrovV.A. (2006) Psychological stress: development and overcoming. Per Se, Moscow, 528 p (In Rus.).

5. Groisman A.L.(2002) Medical psychology. Magistr-Press, Moscow, 452 p. (In Rus.).

6. Sobennikov V.S., Belyalov F.I. (2008) Psychosomatics. Irkutsk University Publ., Irkutsk, 170 p. (In Rus.).

7. Dobrozhanska E.I. (2008) Study of changes in the content of adaptive hormones and the immune system in patients with psoriasis. Ukr. J. Dermatol. Venereol. Cosmetol., 1(28): 9-11. (In Ukr.).

8. Naldi L., Rzani B. (2003) Psoriasis. Evidence-based medicine, 2(6): 1862-1888. (In Rus.).

9. Niemeyer F., Kupfer J. (2008) Educational programs in dermatology: evidence from evidencebased studies in atopic dermatitis and psoriasis. Rus. J. Skin Vener. Dis., 1: 11-21. (In Rus.).

10. de Jager M.E., van de Kerkhof P.C., de Jong E.M., Seyger M.M. (2010) Acrosssectional study using the Children's Dermatology Life Quality Index (CDLQI) in childhood psoriasis: negative effect on quality of life andmoderate correlation of $\mathrm{CDLQ}$ with severity scores. Br. J. Dermatol., 163(5): 1099-1101.

11. de Jager M.E., De Jong E.M., Evers A.W. et al. (2011) The burden of childhood psoriasis. Pediatr. Dermatol., 28(6): 736-737.

12. Khairnasov R.R. (2005) Research of psychological characteristics of men with psoriasis in connection with the tasks of psychocorrectional work. Dis. cand. psychol. sci., Samara State Medical University, Samara, 125 p. (In Rus.).

\section{Відомості про авторів:}

Мурзіна Ельвіна Олександрівна - кандидат медичних наук, доцент кафедри дерматовенерології, алергології, клінічної та лабораторної імунології Національного університету охорони здоров'я України імені П.Л. Шупика, Київ, Україна. ORCID ID: 0000-0002-3440-0745. П'янківська Людмила Володимирівна — кандидат психологічних наук, старший викладач кафедри педагогіки, психології, медичного та фармацевтичного права Національного університету охорони здоров'я України імені П.Л. Шупика, Київ, Україна.

Рохлецова Юліанна Андріївна — студентка факультету психології Київського національного університету імені Тараса Шевченка, Київ, Україна.

Бардова Катерина Олексіївна — кандидат медичних наук, доцент кафедри дерматовенерології, алергології, клінічної та лабораторної імунології Національного університету охорони здоров'я України імені П.Л. Шупика, Київ, Україна.

Адреса для кореспонденції:

Мурзіна Ельвіна Олександрівна

04112, Київ, вул. Дорогожицька, 9

E-mail:elvina2003@ukr.net
13. Gelfand J.M., Weinstein R., Porter S.B. et al. (2005) Prevalence and treatment of psoriasis in the United Kingdom: a population-based study. Arch. Dermatol., 141(12): 1537-1541.

14. Rokhletsova Yu.A., Murzina E.0. (2021) Psychological portrait of teenager with psoriasis. Int. Sci. J. «Grail of Science», 5: 317-320. (In Ukr.).

15. psycabi.net/testy/693-test-oprosnik-kettella-dlya-podrostkov-metodika-14-pf-142-voprosa

\section{Psychological features \\ of adolescents with psoriasis}

\section{E.O. Murzina', L.V. Piankivska', Yu.A. Rokhletsova², K.O. Bardova ${ }^{1}$}

'Shupyk National Healthcare University of Ukraine, Kyiv, Ukraine

${ }_{2}^{2}$ Taras Shevchenko National University of Kyiv, Kyiv, Ukraine

Abstract. Assessment of the psychological characteristics of adolescents with psoriasis at the age of 13-17 years according to the test «R. Cattell's personality factor questionnaire» revealed a low range of personality traits, which are significantly lower than the standard descriptors in 9 out of 14 factors in boys and in 13 out of 14 factors in girls. The results obtained in the study made it possible to determine the psychological profile of boys with psoriasis as cautious, restrained, yielding, superficial in work and in social contacts, sensitive and trusting of loved ones and dependent on significant persons. Inflexibility and slowness in their behaviour can cause misunderstandings and a narrowed social circle. The presence of behavioural reactions with mood variability and multidirectional tendencies of emotional balance can be associated with the characteristics of the disease progression and adolescence. Girls with psoriasis are not sociable enough, cautious and restrained in social contacts, have a feeling of inferiority, which leads to detachment, aloofness and social isolation. They need support and can be obsessive. Manifestations of insufficiently formed emotional-volitional characteristics are manifested depending on the social environment, situations and disease progression.

Key words: psoriasis, adolescents, psychological characteristics, personality traits.

\section{Information about the authors:}

Murzina Elvina 0. - Candidate of Medical Sciences, Associate Professor of Dermatovenereology, Allergology, Clinical and Laboratory Immunology of the Shupyk National Healthcare University of Ukraine, Kyiv, Ukraine. ORCID ID: 0000-0002-3440-0745

Piankivska Ludmila V. — Candidate of Psychological Sciences, Senior Lecturer of the Department of Pedagogy, Psychology, Medical and Pharmaceutical Law of the Shupyk National Healthcare University of Ukraine, Kyiv, Ukraine.

Rokhletsova Yulianna A. — student of the Faculty of Psychology of Taras Shevchenko National University of Kyiv, Kyiv, Ukraine.

Bardova Kateryna 0. - Candidate of Medical Sciences, Associate Professor of Dermatovenereology, Allergology, Clinical and Laboratory Immunology of the Shupyk National Healthcare University of Ukraine, Kyiv, Ukraine.

Address for correspondence:

Elvina Murzina

04112, Kyiv, Dorohozhytska str., 9

E-mail: elvina2003@ukr.net 